Article

\title{
An Analysis about Learning to IncreaseWomen's Participation and Employment in Europe's Energy Transition: Evidence from the European Project MEnS
}

\author{
Elisa Peñalvo-López ${ }^{1}$ (D) and Francisco-Javier Cárcel-Carrasco ${ }^{2, *(D)}$ \\ 1 Instituto Ingeniería Energética, Universitat Politècnica de València, 46022 Valencia, Spain \\ 2 Instituto Tecnología Materiales, Universitat Politècnica de València, 46022 Valencia, Spain \\ * Correspondence: fracarc1@csa.upv.es; Tel.: +34-963-877-000
}

Received: 14 June 2019; Accepted: 7 August 2019; Published: 11 August 2019

check for updates

\begin{abstract}
The Energy Performance Building Directive (EPBD) introduced the requirement for all Member States to include the concept of Nearly Zero Energy Buildings (NZEBs) in their national plans. However, this challenge requires upgrading professional skills in NZEB concepts and strategies, thus guaranteeing the maximum impact on NZEB deployment around Europe. This is the objective of MEnS ("Meeting Energy Professional Skills"), an H2020 project focused on providing high quality upskilling and education to architects, engineers, and building professionals. The role of women in the NZEB industry indicates that female participation in the building industry is still low. The need to rebalance this gender gap is highlighted in this work through the identification of female programs and schemes. In addition, the results of women's participation in the MEnS project is analyzed. The MEns project created and implemented a new education program, training 1200 building managers (engineers and architects) in the designand construction of NZEBs, out of which $46 \%$ were women. Focusing on the Spanish case, 18 interviews were randomly conducted with women participants in order to assess the courses and their expectations of employment in the NZEB framework. The method used for the analysis was a semi-structured interview and analysis by the grounded theory. This article describes the participation of women in this educational program and analyses initial conclusions and lessons learnt from this initiative in 10 European countries, including Spain.
\end{abstract}

Keywords: Nearly Zero Energy Building (NZEB); women empowerment; training; gender equality; women; employability; H2020 European project; architecture; engineering

\section{Introduction}

In Architecture and Engineering studies, the presence and involvement of females rapidly evolved in the Spanish universities and marketplace from 1960s to the 1990s. Women's presence increased from $2 \%$ in 1969 to $29 \%$ in 2013 [1]. Today, there are specific areas that are still resistant to female participation, even though the bulk of university alumni are women. For example, this is the case in some experimental sciences and engineering areas, where women represent less than $30 \%$ of the workforce.

The female Spanish presence in Engineeringis still one of the lowest feminine representations within Spanish Higher Education. In the 2003/04 course, only 28.1\% of the students in the Spanish technical curricula were females at the university level, however, this has increased in the last five years, and currently almost 33\% of graduates are women. Although female presence in engineering careers is approximately one third, the rate of abandonment before graduation is higher among men than among women.

There is a wide distribution of women among the different technical fields.In agronomic engineering the split is close to uniform (50:50 female:male), while in forestry, slightly over 31\% are female, and 
architecture and building engineering rapidly increased to $60 \%$ and $37 \%$ females, respectively. This fact shows the growing interest of women in the building sector. The percentage of women among new students isapproximately between $23 \%$ and $30 \%$ in most of the remaining technical schools, apart from computer sciences, which has a very low presence of women $(11 \%)[1,2]$.

Regarding university researchers/professors, from 2003 to 2013 the situation of this group shows a slow increase in the involvement of women in the different professional categories of university professors. Women among Grade A professors, comparable to "Catedráticas de Universidad" in Spain (the highest category of teaching staff), have increased from 5.6\% in 2003 to $11.95 \%$ in 2013, while in Grade B positions the increment is less significant, from $25.20 \%$ to $27.7 \%$ [3].

The European Commission identified and promoted the need to concentrateon improving energy performance of the EU's building stock in 2000, as a means of reaching 2020 and 2030 energy efficiency targets.Following this, in 2010, a Recast of the Energy Performance Building Directive was published introducing the concept of Nearly Zero Energy Buildings (NZEBs) into the EU legislation, which obliges all new buildings to be NZEBs from 2020 and public buildings from 2018.Responding to this challenge, the construction industry required the ability to provide renovations with novel and contemporary NZEB technologies and designs [4,5]. In light of this, educators must effectively administer high quality training and education to architects, engineers, and building professionals to improve competencies in these areas [6,7].

In the above context, a series of different Horizon 2020 projects where promoted under the construction skills funding scheme. One of these projects was the Meeting of Energy Skills (MEnS), which ran until August 2017. The MEnS goal was to upgrade the NZEB skills for 1800 professionals of the construction sector based on three main educational experiences:

(i) MEnS included an EQF (European Qualification Framework) level 7 educational program for building professionalsin 10 European universities with similar structures, learning outcomes, and accreditations with a total of 10 ECTS (European Credit Transfer and Accumulation System).This educational program was structured in three editions in order to continuously improve it based on the trainers' and trainees' feedback.

(ii) Create a training experience, termed "Front Meeting of Skills (FMS)", based on experiences from real case studies. This training aims to become an open laboratory for designing NZEB solutions in housing stockas well as a think tank of discussion and interactions between involved actors.

(iii) Create an e-learning platform as an interactive portal that promotes distance learning and encourages real debate of stakeholders in the drive to adopt NZEBs in transforming the current building stock.

This article responds to the outcomes associated with FMS (Front Meetings of Skills), a post-graduate education program accredited by the universities with 10 ECTS. The main challenges of MEnS were:

- Refining the learning and competences of at least 1200 building managers (engineers, architects) in NZEB construction and design, out of which $50 \%$ would be women or unemployed.

- Creating and implementing a new training and education program for such professionals in 10 countries, based on desired and common learning outcomes of level 7 and under the European Qualifications Framework provisions.

- Creating and implementing an interdisciplinary, innovative training and education program with an integrated approach, focusing on real case studies

- Accrediting courses using the legal procedure in each country and assigning ECTS credits.

- Enhancing and supporting the development of a professional network in Europe especially focused on retrofitting of housing stocks towards NZEBs.

- Providing working opportunities to unemployed professionals, moving them closer to possible employers and improving their qualifications, at a percentage of $30 \%$ of those attending. 
- Continuing the training courses and education for at least 5 years after the project ends, based on concrete sustainability plans agreed to by the university partners.

In the NZEB context, women professionals, especially those who are mums, are very conscious of sustainable development as part of the future for their children. However, their participation in the construction industry is not very widespread.

In a 2018 study conducted in 26 European nations by the Architects' Council of Europe (ACE), it was estimated that only $39 \%$ of practicing architects are women [8]. One of the important objectives within the MEnS project [9] was to increase the capacities of women in the disciplines of the NZEBs. This article aims to explore, after a brief description of the MEnS project [9], women's participation in this European project. The project focused on the construction industry, on improving the members' ${ }^{\prime}$ ZEB skills, increasing the rate of participation according to gender (male or female), and the rate of employment among participants (emphasizing the highest percentage of unemployment among women). Although the study shows the rates in all the European countries participating in the project, it provides an emphasis on the Spanish case, where the authors of this article had greater participation. Interviews were also conducted in order to analyze the main factors motivating female participation in the coursesand improvingtheir employability. The data obtained can serve other researchers in the design of new projects or further analysis on the subject to improve the skills of architects, engineers, and construction professionals andprovide gender equality.

\section{Materials and Methods}

This section begins with the description of the course program that involved several countries and then describes the methods of data collection through documentary analysis (statistical reports) for the broader context of all participants from the countries involved and the interviews held with 18 women for the Spanish case analyzed through grounded theory.

Training professionals in Nearly Zero Energy Building (NZEB) strategies and technologies was the EQF level 7 educational programs' main goal in order to accelerate the adaptation of the Energy Performance Building Directive (EPBD) of the EU, which implies that all the buildings constructed after the 31st December 2020 will be NZEBs. This date was advanced to 2018in the case of public buildings. According to this condition, the EQL level 7 Educational Program on Nearly Zero Energy Buildings was performed by 10 universities and threemarket players within the framework of the MEnS project.

All major aspects related to Nearly Zero Energy Buildings are taught in each country's program along with the topics of national particularities according to their special needs and challenges. Common topics included in all countries include the following:

- $\quad$ Energy efficiency in the building sector and NZEBs related to European and national policies.

- Advanced techniques, theories, and tools in building modelling.

- Suitable materials and installations for NZEB design and retrofitting.

- Input of renewable energy sources in the building stock.

- Management and economic issues that need to be addressed for professionals to be able to determine the changes required for NZEB design and construction.

Previously, to define MEnS courses that would provide a competitive education course for professionals, an analysis of the European market was performed by project partners. Based on the outcome, universities designed the EQF level 7 courses on NZEBs with the following activities:

- Groundwork of materials encompassing the collection of case studies that were used for practical activities, working examples, tutorials, etc.

- Call for and selection of the participants, consisting of identification of the requirements for trainees in which a certain percentage was devoted to women professionals and the unemployed. In each country, every edition of the course offered EU-funded training to a minimum of 40 professionals. 
- Scheduling of the Education and Training (E\&T) program. All courses in the different countries were scheduled in approximately the same period in order to benefit from the interaction of professionals through e-learning and the MEnS portal.

- Creating the E\&T program delivery plan; with a total of 30 courses, three in each participant country, which represents 1200 trained professionals.

- Gathering and recording participant's assessments and feedback. Participants provided comments that identified recommendations to improve future editions.

EQF level 7 educational activities consisted of designing, implementing, and evaluating specific Education and Training (E\&T) programs for professionals around Europe (architects, engineers, managers, etc.). Courses were delivered by universities that are active in lifelong education in association with market players.Universities handled course delivery and accreditation while market actors and professional associations contributed tothe design of the courses and to continuously evaluating them, so courses were in a continuous improvement process. The aim of this training program was to increase the knowledge and abilities of professional experts in Nearly Zero Energy Building issuesas well asperceiving and assigning the knowledge and competences collected throughout Europe. The EQF level 7 educational program was delivered in 10 universities across Europe in the form of 10 ECTS accredited courses. The participating countries wereGermany (DE), Spain (ES), Ireland (IR), United Kingdom (UK), Greece (EL), Romania (RO), Denmark (DK), Cyprus (CY), FYR of Macedonia (MK), and Belgium (BE).Each of the educational centers offered three editions of the course between December 2015 and June 2017.

This article integrates the results of MEnS's training courses on NZEBs, which were carried out during the project timeline.

Training programs aimed to improve the knowledge and competence of professional experts in Nearly Zero Energy Building aspects, while also granting andcertifying the learning and skills collected within the courses across Europe.All universities accredited their courses with their accreditation office prior to delivering the courses (Table 1). Finally, the effectiveness of the learning process was jointly assessed across the different participant universities using a common questionnaire.

Table 1. Universities and their accreditations.

\begin{tabular}{|c|c|c|c|}
\hline Country & Institution & Course Title & Accreditation Date \\
\hline Spain (ES) & $\begin{array}{l}\text { Universitat Politècnica } \\
\text { de València/Inst. for } \\
\text { Energy Engeenering }\end{array}$ & Professional Energy Skills in NZEB & September 2015 \\
\hline Greece (EL) & $\begin{array}{l}\text { Aristotle University of } \\
\text { Thessaloniki/Power } \\
\text { Systems Laboratory }\end{array}$ & $\begin{array}{l}\text { Nearly-Zero Energy Buildings-Design } \\
\text { and Conversion }\end{array}$ & November 2015 \\
\hline Romania (RO) & $\begin{array}{l}\text { Technical University of } \\
\text { Cluj-Napoca }\end{array}$ & $\begin{array}{l}\text { Tehnici de analiza energeticasi practici } \\
\text { de implementare a cladirilorcuconsum } \\
\text { de energie aproape zero (NZEB) }\end{array}$ & July 2015 \\
\hline FYR of Macedonia (MK) & $\begin{array}{l}\text { Ss. Cyril and Methodius } \\
\text { Univ. in Skopje }\end{array}$ & $\begin{array}{l}\text { Тренингкурсзазградисоенергијаблизуд } \\
\text { (NZEB) задипломираниинженери } \\
\text { иархитекти| Professional Energy Skills } \\
\text { in NZEB }\end{array}$ & гула \\
\hline Ireland (IR) & $\begin{array}{l}\text { Dublin School of } \\
\text { Architecture }\end{array}$ & Professional Energy Skills in NZEB & December 2015 \\
\hline Cyprus (CY) & Univ. of Cyprus & $\begin{array}{l}\text { Building of Integrated Photovoltaics } \\
\text { ("BIPV")-Towards nearly zero energy } \\
\text { buildings (NZEB) }\end{array}$ & December 2015 \\
\hline United Kingdom(UK) & Brunel Univ. London & Nearly Zero Energy Building Retrofit & November 2015 \\
\hline
\end{tabular}


Table 1. Cont.

\begin{tabular}{llll}
\hline \multicolumn{1}{c}{ Country } & \multicolumn{1}{c}{ Institution } & \multicolumn{1}{c}{ Course Title } & Accreditation Date \\
\hline Belgium (BE) & Univ.libre de Bruxelles & $\begin{array}{l}\text { Meeting of Energy Professional Skills } \\
\text { towards NZEB }\end{array}$ & February 2016 \\
\hline Germany (DE) & Univ. Kassel & $\begin{array}{l}\text { Niedrigstenergiegebäude-Standard } \\
\text { fürbestehende Wohngebäude | Nearly } \\
\text { Zero Energy Buildings }\end{array}$ & December 2015 \\
\hline Denmark (DK) & Aarhus University & School of Engineering & October 2015 \\
\hline
\end{tabular}

Focusing on the Spanish case, at the end of the different phases of the training courses, 18 interviews were randomly conducted with various femaleparticipants in order to assess the courses and the women's expectations of employment in the NZEB framework.

The method used for the analysis was a semi-structured interview and analysis by the grounded theory [10-15]. Grounded theoryis used with a very small sample, starting with a general sample of people to begin with the interviews, and then the sample size is adjusted as the research progresses, up to a point of theoretical saturation.In order to obtain information that was not conditioned to the answers of the interviewees, the interviewers followed an interview protocol that was in-depth, semi-structured, and with a flexible style, to extract and understand the experiences from the perspective of the interviewees, all of them college-educated. The interviewees were informants, and in addition to providing relevant aspects, suggested additional sources that could corroborate the evidence [16].

The script of the interview was asfollows:

Studying the factors involved in promoting the participation and employability of women in the European energy transition. Based on your personal experience, answer the following questions:

(i) Do you think that these courses framed within the MEnS project have served to improve the capacity of women to use of NZEB technologies?

(ii) How do you think it will affect their employability or improve their employment?

(iii) What are the barriers or disadvantages that may influence a higher rate integration of women in the construction sector?

(iv) What may be improved in the training program to improve women's employment?

The interviews were conducted after the completion of the different courses within the Polytechnic University of Valencia (Spain). During the interview process, the terms used were defined, clarifying the doubts that emerged among the participants. The attitude of all respondents was active and collaborative.

Data analysis of the interviews was carried out by examining the transcribed interviews, the notes, and observations madeduring the interview and throughrevisionbased on related studies and literature. This process allowed for the analysis of a cluster of data and comparison with other evidence [17,18]. The interviews were analyzed individually and in cross-based categories as described by Maxwell strategies [19].

\section{Results}

This section starts with the description of the participants in the involved countries, considering diverse variables such as the number of participant professionals per country, the professions in the MEnS courses, nature of employment of the participants, professional experience of the participants, unemployed professionals in each country, female participation in each country, etc. Next, it describes the participants' interviews (focusing on the Spanish case) and lists and defines the categories used to evaluate the data consistency.

Within the three editions of the MEnS courses across Europe, the university partners trained 1206 professionals in 5547 training hours, with great success among the building and construction sector. Professional response was very positive from the beginning, acknowledging the need for such specific 
training.The optimal number of participants was fixed in for each university in meetings with the partners of the project based on the experience of the participating institutions.

The highest course participation in NZEB courses was observed in Romania, Greece, FYR of Macedonia, and Spain (Figure 1), while countries like Denmark or Belgium did not have as many professionals attending the courses (Table 2). This is mainly because unemployment is relatively low in these countries and currently the construction sector is very busy.

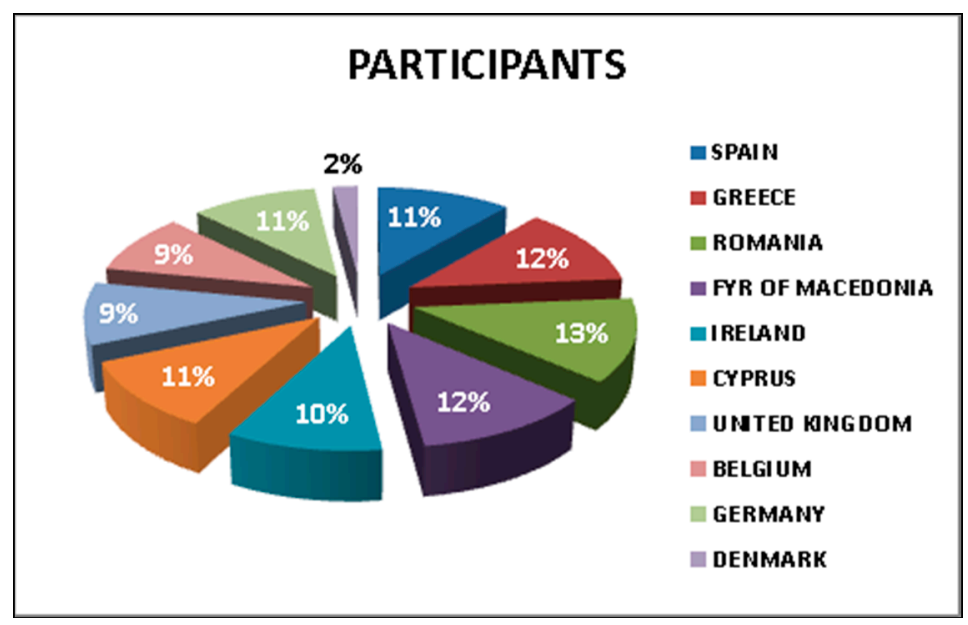

Figure 1. Percentage of participants per country.

Regarding the professions of the participants (Figure 2), results showed that the participants were mostly from architectural and engineering disciplines, mainly electrical and civil/structural engineers. Nevertheless, other professionals related to the construction sector, such as building and facility managers have also started to pay attention to the Nearly Zero Energy Building concept and the benefits associated to minimizing energy consumption and increasing the contribution of renewable energy sources as suggested by their attendance in the courses.

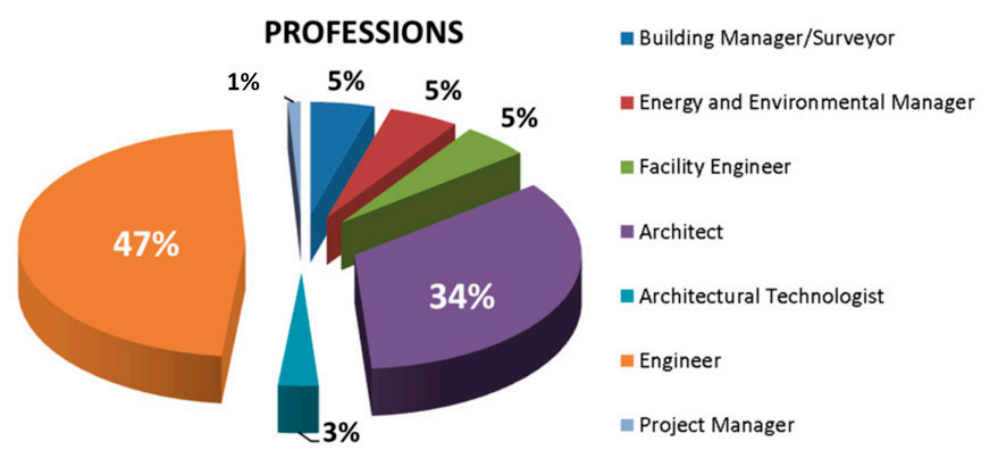

Figure 2. Professions in the Meeting Energy Professional Skills (MEnS) courses.

Analyzing the nature of the employment (Figure 3), professional experience (Figure 4), and unemployment rate (Figure 5), it was observed that the majority of the participants were employed by the private sector, self-employed, or freelance and had less than 10 years of experience.This is because one of the specific objectives of the MEnS project was to focus on the unemployed community and upskilling their NZEB competencies so they could have a better chance to find a job. 
Table 2. Number of attendees professionals per country.

\begin{tabular}{|c|c|c|c|c|c|c|c|c|c|c|c|}
\hline Country & Accreditation & 1st Ed & $2 d \mathrm{Ed}$ & 3rd Ed & $\begin{array}{l}\text { Num. of } \\
\text { Architects }\end{array}$ & $\begin{array}{l}\text { Num. of } \\
\text { Engineers }\end{array}$ & $\begin{array}{l}\text { Other } \\
\text { Profess. }\end{array}$ & $\begin{array}{l}\text { Num. of } \\
\text { Women }\end{array}$ & $\begin{array}{c}\text { Num. of } \\
\text { Unemployed }\end{array}$ & Participants & Training hours \\
\hline Spain & Yes & 42 & 40 & 55 & 67 & 64 & 6 & 64 & 91 & 137 & 300 \\
\hline Greece & Yes & 40 & 58 & 50 & 36 & 112 & 0 & 82 & 33 & 148 & 750 \\
\hline Romania & Yes & 45 & 48 & 60 & 30 & 111 & 12 & 63 & 18 & 153 & 300 \\
\hline FYR of Macedonia & Yes & 44 & 48 & 48 & 27 & 113 & 0 & 77 & 49 & 140 & 750 \\
\hline Ireland & Yes & 40 & 40 & 40 & 67 & 26 & 27 & 55 & 10 & 120 & 600 \\
\hline Cyprus & Yes & 41 & 43 & 44 & 28 & 96 & 4 & 44 & 70 & 128 & 627 \\
\hline United Kingdom & Yes & 32 & 31 & 52 & 11 & 91 & 13 & 36 & 70 & 115 & 600 \\
\hline Belgium & Yes & 36 & 38 & 38 & 20 & 22 & 70 & 64 & 60 & 112 & 360 \\
\hline Germany & Yes & 40 & 41 & 47 & 55 & 58 & 15 & 67 & 7 & 128 & 900 \\
\hline \multirow[t]{2}{*}{ Denmark } & Yes & 9 & 10 & 6 & 7 & 5 & 13 & 11 & 10 & 25 & 360 \\
\hline & Totals & 369 & 397 & 440 & 348 & 698 & 160 & 563 & 418 & 1206 & 5547 \\
\hline
\end{tabular}




\section{NATURE OF EMPLOYMENT}

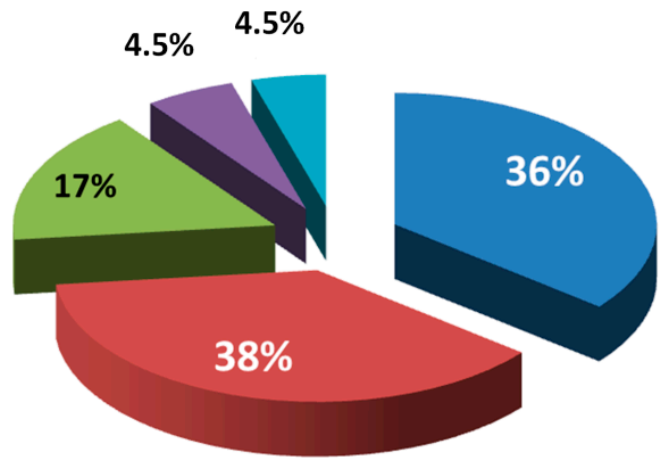

- Self-employed or free-lance

Employee private sector

Employee public sector

Employee not-for profit organisation

noth employee and free-lance at the same time

Figure 3. Nature of employment of participants.

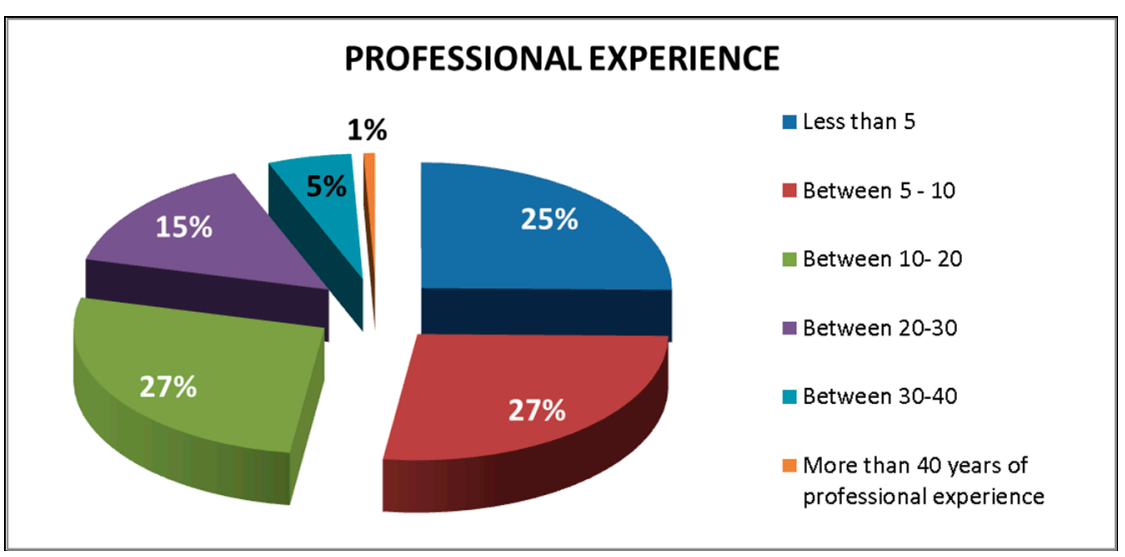

Figure 4. Experience of participants.

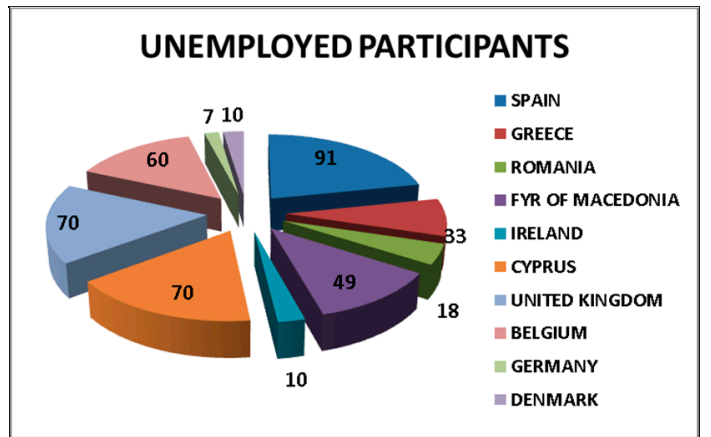

(a)

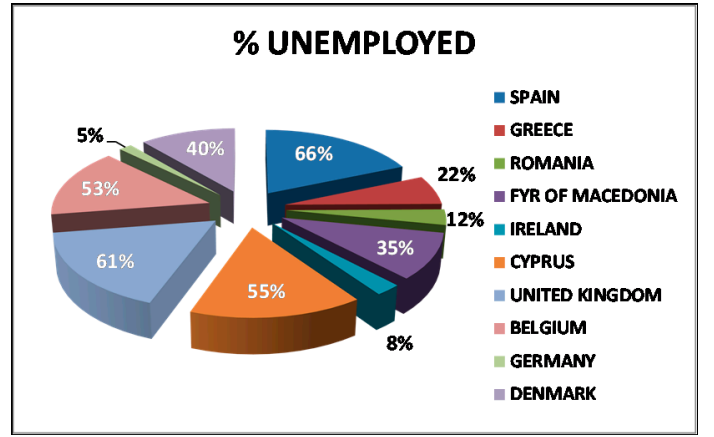

(b)

Figure 5. in each country. (a) By number participants. (b) By \% participants (Each \% represents the percentage of unemployed participants in MEnS project in those countries).

As shown in Table 2, a total of 418 unemployed professionals were trained, representing $32 \%$ of the total trained professionals.

Another important target within the MEnS project was increasing the capabilities of women in NZEB disciplines (Figure 6). 


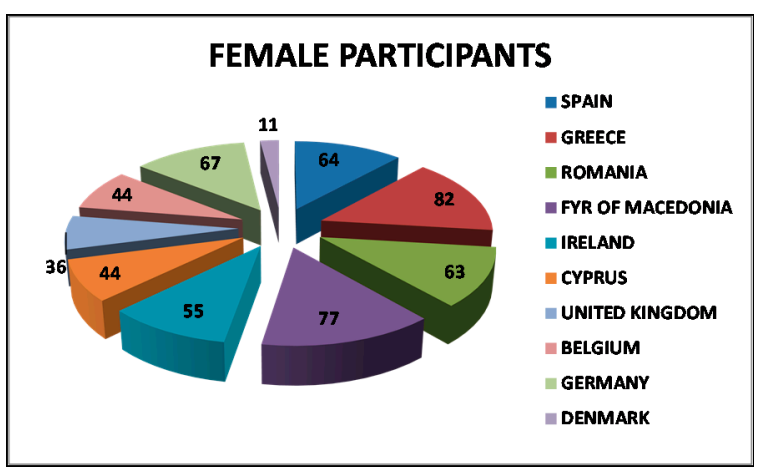

(a)

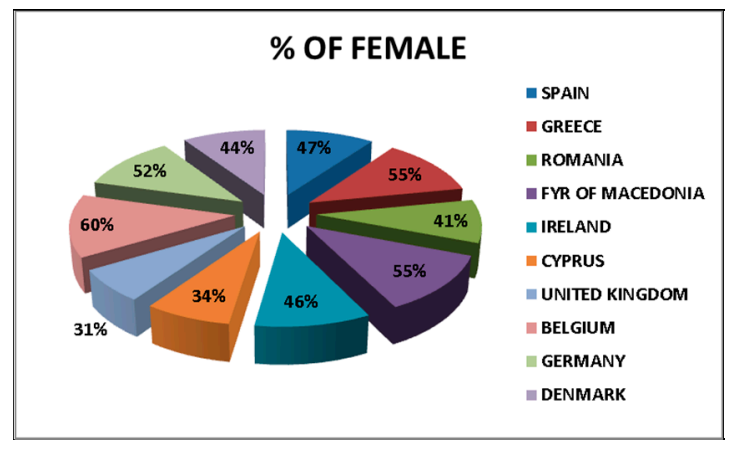

(b)

Figure 6. in each country. (a) By number participants. (b) By \% participants (Each \% represents the percentage of female participants in MEnS project in those countries).

The unemployment rate of engineers in the labor market is approximately $7 \%$ in the case of males and $29 \%$ in the case of females [1,3].Men's presence among the employed is quite a bit higher in universities and in industry. Oddly, the percentage of women dedicated to research activities in non-profit private institutions is higher than that of men. In 2012, $89 \%$ of employed women worked in the services sector, in contrast with the $8 \%$ in industry and $2 \%$ in agriculture.Thus, it becomes evident that industry and business is still a male world. This situation occurs at all levels, but it is in the highest professional scales where the small female presence becomes alarming. Female percentage in executive manager job positions is below the $10 \%$, while it is $0.9 \%$ in the general manager category $[20,21]$, as shown in Figure 7.

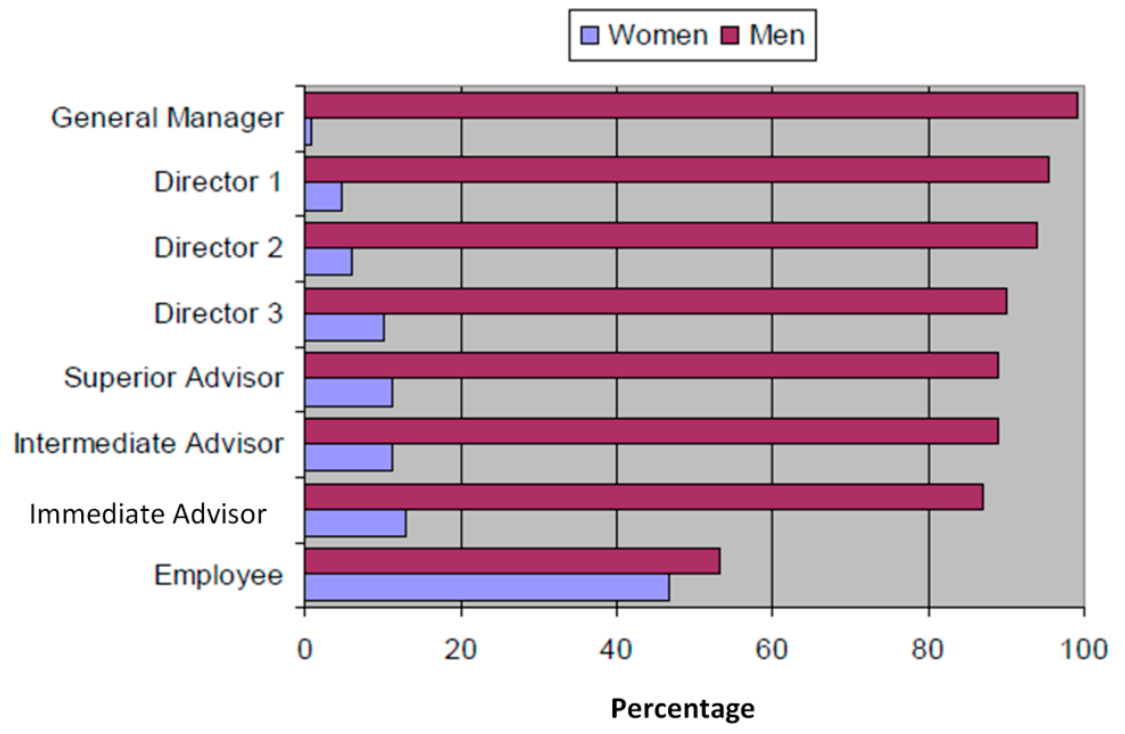

Figure 7. Male and female employment in companies in Spain.

Based on the participants'interviews (focusing on theSpanishexperience), a list of categories was defined to evaluate the data consistency [19]. The list of categories wasdefined during data collection. Using the grounded theory, we identified the research questions and summarized of the interviews. This list was modified throughout the field work and analysis of the cases. The categorization of the data of each one of the cases was an iterative process in which initially data were assigned to the following categories:

- Promotion of women's participation in the NZEB construction concept: Activities that support the participation of women in the building sector. 
- Important elements for improving employability: Individual and organizational actions that support or limit the employability of women in the sector.

- Barriers in women's employability in the building sector: Formal and informal factors that enhance women'sparticipation in NZEB adaptations. Formal mechanisms may be easily used by any member of the organization. Informal mechanisms may help transfer knowledge through direct contact, peer-to-peer.

- Specific training program to promote women's employment: Definition of new training programs capable to upskilling women's capacities in NZEB.

\section{Discussion}

Despite the differences in men's and women's employment, many Spanish universities are showing a positive trend, promoting "girl's day" and other initiatives to enhance the participation of women in technical degrees. Similarly, private organizations are slowly incorporating new gender equality policies, such as "Gender Equality Plans" in the workplace [3,22].

\subsection{Existing Activities and Schemes for the Promotion of Female Engineers and Building Professionals}

Many of the activities, schemes, and organizations in Spain for the promotion of females in the engineering and building industry are international. The national and international organizations accessible for Spanish women engineers are as follows:

- MUCIT-Asociación de Mujeres Científicas y Técnicas (Association for Scientific and Technical Woman). This is a regional association raising awareness and encouraging open debate on topics relating to women and science and technology, with the aim of persuading society that the topics are not problems specific to women but affect the whole of humanity [20].

- AMIT-Asociación de Mujeres Investigadoras y Tecnólogas (Association for Woman in Research and Technology). This is a non-profit and inclusive association aiming to be the voice and support network for all researchers and universities in order to achieve the full participation of women in research and science [23].

- Institute of Electrical and Electronics Engineers IEEE Women in Engineering (WIE)—Spain. This is an affinity group within the IEEE, which is the largest professional organization in the world with over 300,000 members.WIE Spain is the Spanish Chapter, responsible for organizing and coordinating the activities of WIE in Spain [24].The IEEE Women in Engineering (WIE), which is the largest international professional association for women engineers and scientists, inspires girls to follow their academic interests to a career in engineering. They are active on a global level, but do have local activities in Spain as well $[25,26]$.

- WiSET-Women in Science, Engineering and Technology. The main aim of the WiSET network is to broaden women' participation in science, technology, engineering, maths, and the building environment. They have developed and launched a large range of contemporary programs and activities based on gender and occupational partition at all education and employment stages [24].

- Women in Engineering Society. The Women in Engineering Society initiates goals to regulate the gender inequality of the area. Some key targets of the program are boosting the profiles of talented female engineers and enlarging the general understanding of engineering through events [27].

- IET Women's Network. The IET (Institution of Engineering and Technology) Women's Network was set up in order to engage with the under-represented groups within engineering and technology. It supports female engineers throughout their careers [28].

- Athena Swan Charter. Equality Challenge Unit-ECU's Athena SWAN Charter was established in 2005 to promote the enhancement of women in careers in engineering, technology, science, maths, and medicine (STEMM) and employment in research and higher education [21]. 


\subsection{Unemployed and Female}

As shown in Table 2, a total of 418 unemployed professionals were trained. A higher unemployment rate was noted in Spain, where 91 participants were actively searching for a job. Other countries with a significant percentage of unemployed professionals participating in the courses were Cyprus (70), United Kingdom (70), and Belgium (60), mainly because participants were graduate students finalizing their post-graduate programs.In contrast, courses organized in Germany (7), Denmark (10), Ireland (10), and Romania (18) included experienced professionals actively involved in the market.

Another important target within the MEnS project was increasing the capabilities of women in NZEB disciplines.In this regard, an important effort was made to involve women in the courses. As observed in Figure 7, 563 female building professionals were trained, mainly in Greece (82), FYR of Macedonia (77), Germany (67), Belgium (64), and Spain (64), which represented 55\%, 55\%, 52\%, 57\%, and $47 \%$ of attendees, respectively.

\subsection{Female Participation in NZEB Courses Across Europe}

The EQF level 7 educational program involved the organization of three editions of the academic courses per university. Within theses three editions, the 10 participant universities have trained a total of 1206 building professionals during 5547 training hours.

The female presence was high in all editions; a total of 563 trainees were women, which represented $46 \%$ of the total building professionals involved in the training courses offered by the universities (Figure 8).

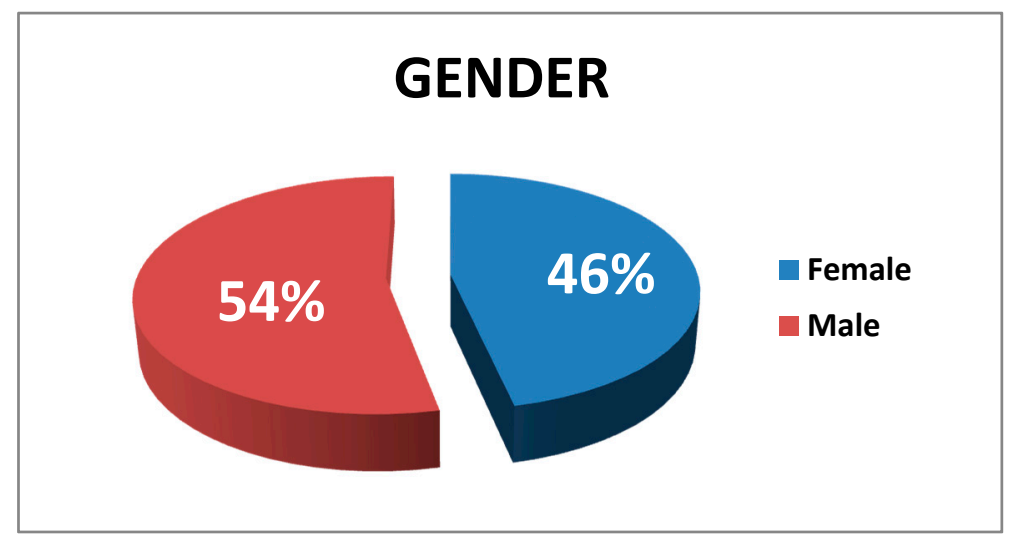

Figure 8. and female participation in MEnS training courses.

The highest participation of women was observed in the courses carried out at Aristotle University of Thessaloniki in Greece was the university training more female professionals, specifically 82 out of 148 participants (55\%) (Figure 9). The other universities with female participation over $50 \%$ in the courses wereSs. Cyril and Methodius University in Skopje (FYR of Macedonia) with 77 out of 140 participants and Universität Kassel (Germany) with 67 out of 128 participants, corresponding to $55 \%$ and $52 \%$, respectively. 


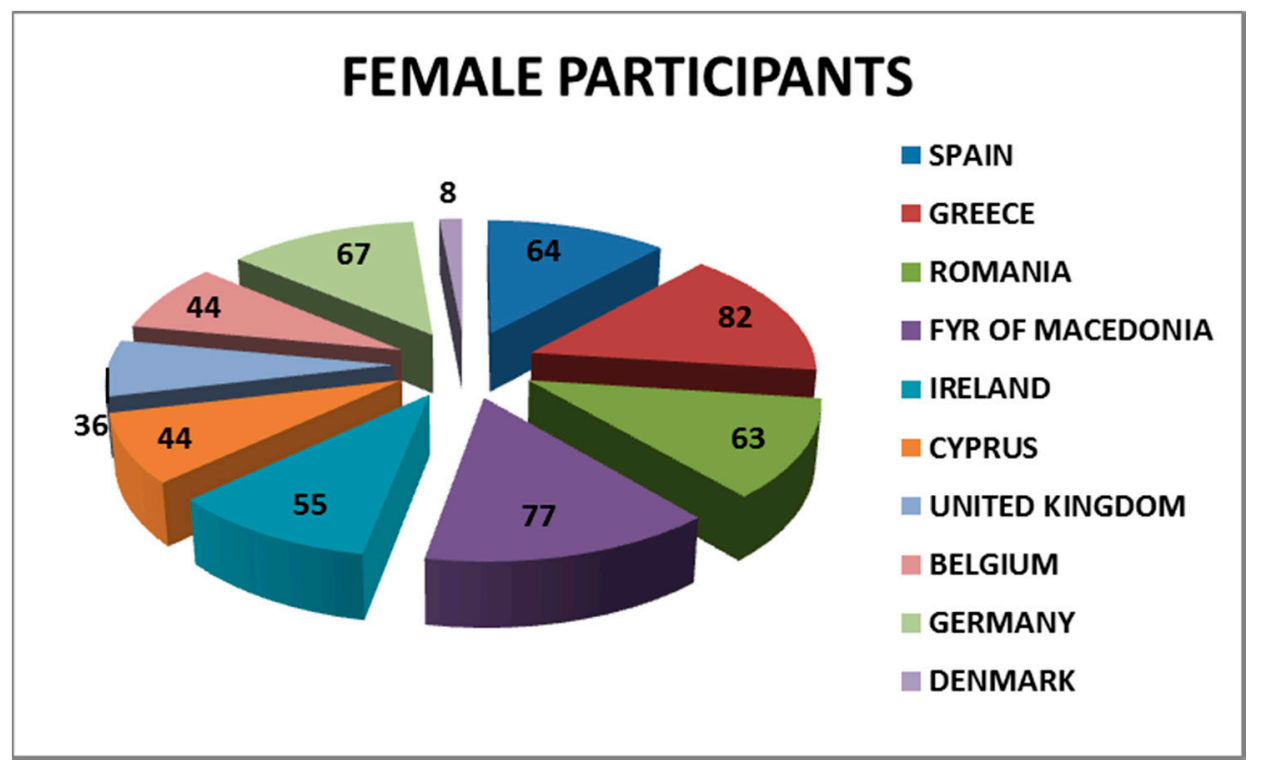

Figure 9. Number female participants per country.

The lowest participation of women was observed at Brunel University London (United Kingdom) and EC Network in collaboration with Aarhus University (Denmark), which registered just 36 out of $115(31 \%)$ and 8 out of 19 (42\%) participants, respectively (see Figures 9 and 10).

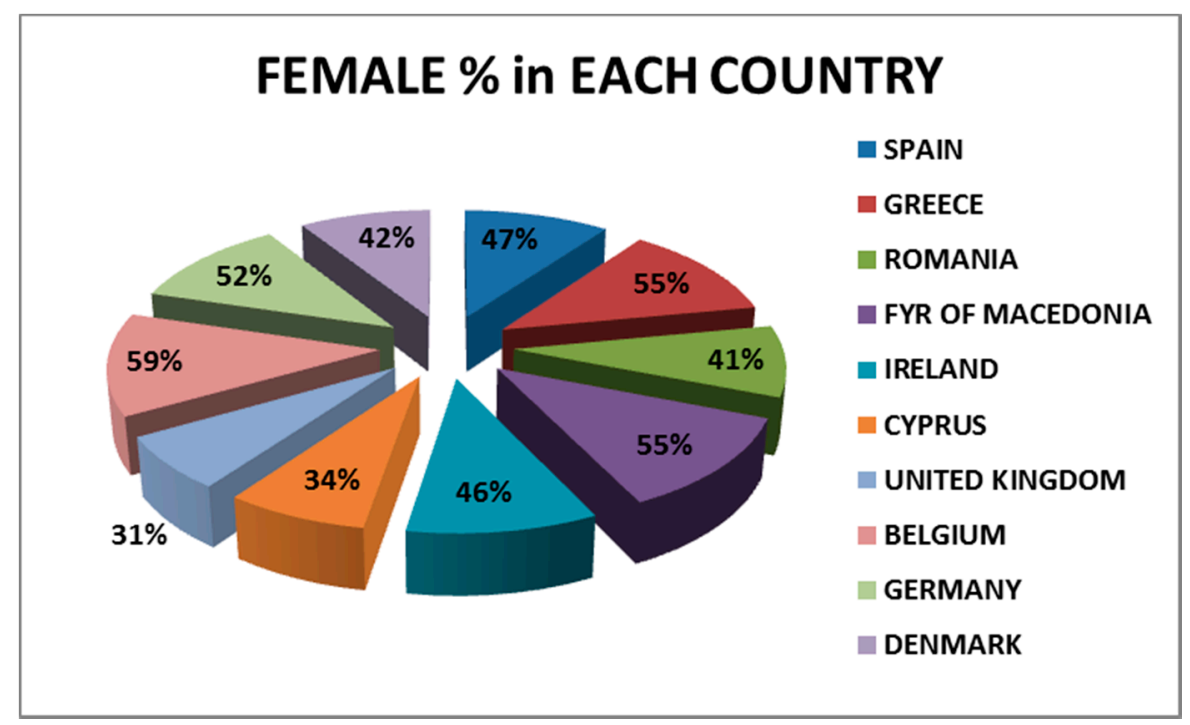

Figure 10. Percentage of participation of female building professionals per country (Each \% represents the percentage of female participants in MEnS project in those countries).

In the case of Spain, Universitat Politècnica de València through the Institute for Energy Engineering trained a total of 64 women out of 137 professionals, in other words, $46 \%$ of participants were female building professionals (see Table 3). 
Table 3. Number of participants per university.

\begin{tabular}{llccc}
\hline \multicolumn{1}{c}{ Country } & \multicolumn{1}{c}{ University } & CourseParticipants & NumberofFemale Participants & Female \\
\hline Spain (ES) & $\begin{array}{l}\text { UniversitatPolitècnica de València/ } \\
\text { Inst. for Energy Engeenering. }\end{array}$ & 137 & 64 & $47 \%$ \\
\hline Ireland (IR) & Dublin School of Architecture & 120 & 55 & $46 \%$ \\
\hline Romania (RO) & $\begin{array}{l}\text { Technical University of } \\
\text { Cluj-Napoca }\end{array}$ & 153 & 63 & $41 \%$ \\
\hline Greece (EL) & $\begin{array}{l}\text { Aristotle University of } \\
\text { Thessaloniki/Power Systems Lab. }\end{array}$ & 148 & 82 & $55 \%$ \\
\hline Cyprus (CY) & University of Cyprus & 128 & 44 & $34 \%$ \\
\hline FYR of Macedonia (MK) & $\begin{array}{l}\text { Ss. Cyril and Methodius Univ. in } \\
\text { Skopje }\end{array}$ & 140 & 77 & $55 \%$ \\
\hline United Kingdom (GB) & Brunel University London & 115 & 36 & $31 \%$ \\
\hline Belgium (BE) & Universitélibre de Bruxelles & 112 & 64 & $57 \%$ \\
\hline Germany (DE) & Universitaet Kassel & 128 & 67 & $52 \%$ \\
\hline Denmark (DK) & Aarhus University & 25 & 11 & $44 \%$ \\
\hline & & Source: [29]. & &
\end{tabular}

\subsection{Analysis of the Interviews}

In the analysis of data from the interviews, the main factors involved in the participation of women in the NZEB sector as well as the barriers to their participation were detected. Similarly, formal and informal mechanisms to improve their employability in the building sector wereidentified.

Promotion of women's participation in the NZEB concept: Although field studies in architecture and engineering have traditionally been male-focused [30-33], in recent years, the gap between men and women has been decreasing [34,35]. The promotion of training courses to improve women's capabilities in NZEB tools and skills will increase the participation of females in this expertise area, which is currently occupied mainly by men. The analysis of the interviews showed that most of the women are completing the training so they can enter a sector of building that is focused on the future. Greater inclusion of women in the building sector throughout the different associations of engineers and architects and the support of the private sector should be encouraged. Similarly, actions promoting women in the last years of university education would also increase the participation of women in the sector.This excerpt from one of the interviews, "[...] these courses have helped me to see new lines of work with the knowledge of new technologies in a sector of the future [...] and to strengthen my security in the face of new work challenges [...]", outlines concepts that were repeated by the majority of those interviewed.

Important elements for improving employability:Employability means thatprofessionalshave the capabilities they need to find a job or launch their own. In return, it provides the private sector with qualified, motivated, and dedicated staff capable of increasing the competitiveness and prosperity of their businesses [36-39]. The analysis of the interviews showed thatNZEB specialization promotes women's access to employment in consulting firms. Like wise, female participants manifested the need for further actions among construction companies that would encourage equal gender plans. Subcontractors, installers, and manufacturers of materials and equipment wereidentified as the main sources of employment.This excerpt from one of the interviews, “[ ... ]specialization in NZEB believe that it will help me to form my own consulting company [ ... ] there should be more women in subcontractors, materials manufacturers, where there is currently a greater demand for employment [ ... ] and there is little female participation", outlines concepts held by the majority of those interviewed.

Barriers in women's employability in the building sector:There is a direct relationship between academic training and women's employability [40-42], the level of education and employability is especiallyinterlinked in their case [42]. It would be interesting to investigate if the reduced number of females participating in building engineering and architecture is related to the existing gender barriers in the construction sector. Delving into women'spreferences for choosing university studies, 
the differences between men and women are evident, which reveals the possible existence of cultural or social barriers that limit the presence of women in the construction industry.It is extracted from the analysis of the interviews that the main barrier for women's employability in the construction sector is cultural. This barrier could be removed through the organization of women's talks encouraging other women to work in the building industry, as well as informative actions among construction companies that eliminate gender barriers. This excerpt from one of the interviews, " $[$... ] when I started my engineering studies we were few women in class [ ... ] most of my female friends have studied in social areas (medicine, law, teacher, etc.) [ ... ] my parents believed that they were not suitable studies for women [ ... ] I think it is a cultural barrier that must be broken, encouraging the entry of women into engineering and architecture studies [ ... ]", outlines concepts constantly repeated by most of those interviewed.

Specific training program to promote women's employment: Although the specific NZEB training conducted during the MEnS project was assessed very positively by all respondents, the need for further participation of construction companies in the training courses was also noted. This would help to understand to a greater extend the needs of construction companies andto acquire practical training that would help employability in the sector. Also, it was determined from the data analysis the importance of promoting discussion forums among the students from different countries. This benefited the internationalization of the professionals in theEuropean labor market and increased the participation of women in the sector. This excerpt from one of the interviews, "[ ... ] it would be interesting to have a greater participation of construction companies in these courses, this gives women a more realistic vision of the needs of these companies, and the role that women can play, contributing our point of view [...] I think it is necessary to generate discussion forums among women on this subject [...] these courses have helped me to see the vision of other women in other countries [...] and form new professional relationships", outlines concepts maintained by many of those interviewed.

\section{Conclusions}

Women's participation in engineering and architectural disciplines is rapidly increasing, which denotes the interest of female professionals in the building sector.However, the building sector still lacks women in high professional positions within the organizations, such as executive management positions or research institute directors. In this regard, there exist many different organizations supporting and promoting women's contributions to engineering and technology areas through association and networking.

The European project MEnS (Meeting of Energy Skills) focused on upskilling building professionals in the NZEB concept, paying special attention to the unemployed community in the selection process. Furthermore, the project aimed to promote a more active participation of women in the construction sector by upskilling their abilities towards NZEB design and strategies. In this regard, 563 female building professionals were trained.

The highest female participation was at the Aristotle University of Thessaloniki (Greece), Ss. Cyril and Methodius University in Skopje (FYR of Macedonia), and Universität Kassel (Germany), with 82 out of $148(55 \%)$, 77 out of $140(55 \%)$, and 67 out of 128 (52\%) participants, respectively. In the case of Universitat Politècnica de València, the Institute for Energy Engineering trained a total of 64 female building professionals out of 137 (46\%).

In reference to the analysis of interviews, the need for specific courses to train women in novel NZEB skills and tools to increase their interest and participation in this area of expertise, which is currently occupied mainly by men, was highlighted. More training courses similar to MEnS should be promoted together with dissemination activities that encourage gender equality plans in the construction sector.Similarly, promotional actions for female university students in engineering and architecture could increase the participation of women in the building sector. The study also highlighted the importance of the cultural and social components as one of the main barriers for female participation in the sector. Dissemination activities such as specific forums and events for women 
engineers and architects are necessary to overcome these barriers. It would be very interesting to create groups of women from various countries to discuss the main drawbacks and barriers in their national construction sectors and how to confront them together. This will also increase the internationalization of women in the European market and their visibility in the NZEB labor market.

Author Contributions: E.P.-L. prepared the conceptualizationand data curation; F.J.C.-C. gathered and analyzed the data; and F.J.C.-C., together with E.P.-L., wrote the paper.

Funding: This research was funded by the European Commission, grant number Ref. 649773.

Acknowledgments: This initiative responds to a common effort between 10 European universities and three market players, funded by the "Meeting of Energy Skills (MEnS)" Horizon 2020 project (Ref. 649773).The work was completed by the Institute for Energy Engineering located at the Universitat Politècnica de València. The authors deeply thank the Universitat Politècnica de Valencia and all the people and organizations involved in this project for their support and, specifically, the European Commission for their funding provision.

Conflicts of Interest: The authors declare no conflict of interest.

\section{References}

1. Sánchez de Madariaga, I. Gender Statistics at Universidad Politécnica de Madrid; Fundación General de la Universidad Politécnica de Madrid: Madrid, Spain, 2014.

2. Peñalvo-López, E.; Cárcel-Carrasco, F.J.; Morcillo, A.; Alvarez, C. Empowering women participation in Europe's energy transition through the deployment of Nearly Zero Energy Buildings. In Proceedings of the INNODOCT 2017, Valencia, Spain, 25-27 October 2017.

3. Baldassarri, S. Female Presence in the IEEE in Spain: The Spanish Women in Engineering Group WIE_Spain. In Proceedings of the 3rd International Conference on Inter-Disciplinarity in Education (ICIE 2007), Athens, Greece, 5-7 February 2007.

4. Spanish Ministry of Development. Long-Term Strategy for Energy Renovation in the Building Sector in Spain Pursuant to Article 4 of Directive 2012/27/UE; Ministerio de Fomento: Madrid, Spain, 2014.

5. European Commision. Directive 2010/31/EU of the European Parliament and of the Council of 19 May 2010 on the Energy Performance of Buildings. EURO Lex: OJ L153. 2010, Volume 18, pp. 13-35. Available online: http://eur-lex.europa.eu/legal-content/EN/ALL/;ELX_SESSIONID= FZMjThLLzfxmmMCQGp2Y1s2d3TjwtD8QS3pqdkhXZbwqGwlgY9KN!2064651424?uri=CELEX: 32010L0031 (accessed on 20 March 2018).

6. Peñalvo-López, E.; Cárcel-Carrasco, F.J.; Devece, C.; Morcillo, A. A methodology for analysing sustainability in energy scenarios. Sustainability 2017, 9, 1590. [CrossRef]

7. Cárcel-Carrasco, F.J.; Peñalvo-López, E.; De Murga, G. Oficinas auto-sostenibles para las agencias de ayuda internacional en zonas geográficas remotas. DYNA 2018, 93, 272-277. [CrossRef]

8. ACE Architects' Council of Europe. The Architectural Profession in Europe. 2018. Available online: https://www.ace-cae.eu/ (accessed on 2 July 2019).

9. MEnS Consortium. Meeting of Energy Professional Skills (MEnS) Platform. Available online: http: ///www.mens-NZEB.eu/en/ (accessed on 8 May 2018).

10. Partington, D. Building grounded theories of management action. Br. J. Manag. 2000, 11, 91-102. [CrossRef]

11. Charmaz, K. Constructing Grounded Theory: A Practical Guide through Qualitative Analysis; SAGE: London, UK, 2006.

12. Douglas, D. Grounded theory and the "And" in entrepreneurship research. Electron. J. Bus. Res. Methods 2004, 2, 59-68.

13. Eich, D. A grounded theory of high-quality leadership programs: Perspectives from student leadership development programs in higher education. J. Leadersh. Organ. Stud. 2008, 15, 176-187. [CrossRef]

14. Glaser, B.G.; Strauss, A.L. Discovery of Grounded Theory: Strategies for Qualitative Research; Routledge: New York, NY, USA, 2017. [CrossRef]

15. Hardy, M.; Bryman, A. Handbook of Data Analysis; Sage Publications: London, UK, 2004.

16. Casey, D.; Houghton, C. Clarifying case study research: Examples from practice. Nurse Res. $2010,17$. [CrossRef] [PubMed]

17. YIN, R.K. Case Study Research: Design and Methods; Sage Publications: Thousand Oaks, CA, USA, 1995.

18. Eisenhardt, K.M. Building theories from case study research. Acad.Manag. Rev. 1989, 14, 532-550. [CrossRef] 
19. Maxwell, J.A. Qualitative Research Design: An Interactive Approach; Sage Publications: London, UK, 2012; Volume 41.

20. AMIT (Asociación de MujeresInvestigadoras y Tecnólogas). Available online: http://www.amit-es.org/ (accessed on 6 June 2015).

21. ATHENA SWAN. Gender Charter. Available online: http://www.ecu.ac.uk/equality-charters/athena-swan/ (accessed on 7 May 2015).

22. INE. Women and Men in Spain 2014; Instituto Nacional de Estadística: Madrid, Spain, 2015.

23. MUCIT. Asociación de MujeresCientíficas y Técnicas. Available online: http://www.unizar.es/mutem/mucit. html (accessed on 21 June 2015).

24. WiSET. About WiSET. Available online: http://www.wiset.org.uk/index.php?page=introduction (accessed on 20 May 2017).

25. WIE-Spain. IEEE Women in Engineering. Available online: http://www.dinel.us.es/wie/ (accessed on 3 June 2017).

26. IEEE. IEEE Women in Engineering. Available online: http://www.iee.org/membership_services/membership/ women/index.html (accessed on 11 May 2018).

27. University of Sheffield. Women in Engineering. Available online: http://womeninengineering.org.uk/aboutus/ (accessed on 14 May 2017).

28. IET. The IET Women's Network. Available online: http://mycommunity.theiet.org/communities/home/77? origin=wnmyc\#.VWsFzl5N1uY (accessed on 22 May 2015).

29. Peñalvo-López, E.; Cárcel-Carrasco, F.J.; Christoforidis, G.C.; Nousdilis, A.; Riccettid, A.; Melandri, D.; Papagiannis, G.K. Upgrading Qualifications of European Energy Professionals in NZEB-TheMEnS Project. Procedia Environ. Sci. 2017, 38, 898-904.

30. CALCIA INFOS. Prix des Femmes architectes 2013. Available online: http://www.calcia-infos.fr/innovations/ prix-des-femmes-architectes-2013 (accessed on 20 October 2016).

31. Navarro-Astor, E.; Román-Onsalo, M.; Infante-Perea, M. Revisióninternacional de estudios de barreras de carrera bajo la perspectiva de géneroen la industria de la construcción. Innovar 2016, 26, 103-117. [CrossRef]

32. Agapiou, A. Perceptions of gender roles and attitudes toward work among male and female operatives in the Scottish construction industry. Constr. Manag. Econ. 2002, 20, 697-705. [CrossRef]

33. Sandra, L.; Fielden Marilyn, J.; Davidson Andrew, W.; Caroline, G.; Davey, L. Women in construction: The untapped resource. Constr. Manag. Econ. 2000, 18, 113-121. [CrossRef]

34. Andrew, R.J.; Dainty Barbara, M.; Richard, B.; Neale, H. A grounded theory of women's career under-achievement in large UK construction companies. Constr. Manag. Econ. 2000, 18, 239-250. [CrossRef]

35. Whittock, M. Women's experiences of non-traditional employment: Is gender equality in this area a possibility? Constr. Manag. Econ. 2002, 20, 449-456. [CrossRef]

36. Azhar, S.; Griffin, M.K.A. Women in construction: Successes, Challenges and Opportunities-A USACE Case Study. In Proceedings of the 50th ASC Annual International Conference, Washington, DC, USA, 26-28 March 2014; Available online: http://ascpro0.ascweb.org/archives/cd/2014/paper/CPRT249002014.pdf (accessed on 6 March 2018).

37. Francis, V.; Prosser, A. Exploring vocational guidance and gender in construction. Int. J. Constr. Educ. Res. 2014, 10, 39-57. [CrossRef]

38. Kaewsri, N.; Tongthon, T. Favorable Female Attributes in Relation to Career Challenges of Women Engineers in the Thai Construction Industry. Int. J. Constr. Educ. Res. 2014, 10, 222-236. [CrossRef]

39. Navarro-Astor, E.; Caven, V. The Professional Career of Spanish Architects: Obstacles and Facilitators. In Construction and Building Research; Springer: Dordrecht, The Netherlands, 2014. [CrossRef]

40. Sang, K.; Dainty, A.R.J.; Ison, S.G. Gender in the UK architectural profession: (Re)producing hegemonic masculinity. Work Employ. Soc. 2014, 28, 247-264. [CrossRef] 
41. Stephen Sewalk, P.H.D.; Nietfeld, J.D.K.; RECM, M.S. Barriers Preventing Women from Enrolling in Construction Management Programs. Int. J. Constr. Educ. Res. 2013, 9, 239-255. [CrossRef]

42. Infante, M.; Román, M.L.; Traverso, J.; Torres, M. La formación universitaria como factor de empleabilidad y estabilidad de la mujeren el sector de la construcción. In Proceedings of theInvestigacionesmultidisciplinaresengénero: II Congreso Universitario Nacional Investigación y Género. [libro de actas], Sevilla, Spain, 17-18 June 2010; pp. 513-534. Available online: https://idus.us.es/xmlui/ handle/11441/40314 (accessed on 6 March 2018). 